\title{
SA’s happiness - and misery - index
}

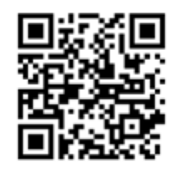

Measuring a nation's happiness - Gross National Happiness $(\mathrm{GNH})$ - in the manner of measuring Gross National Product (GNP) would seem frivolous, but is increasingly being taken seriously. ${ }^{[1]}$ Happiness has come to be considered a measure of social progress. Psychologists, economists and sociologists have shown that people's satisfaction with their lives offers information about a society. National governments have begun to use measures of happiness, or subjective wellbeing, to guide development of policies aimed at improving people's lives. ${ }^{[1]}$ The idea of measuring GNH, and developing a GNH index, ${ }^{[1]}$ began in the tiny constitutional monarchy of Bhutan, tucked against the Himalayas, with (just) 800000 citizens. ${ }^{[2]} \mathrm{GNH}$ is a complex mathematical construct $^{[1]}$ that provides an overview of performances across nine domains (psychological wellbeing, time use, community vitality, cultural diversity, ecological resilience, living standard, health, education, good governance) each with a number of key indicators, e.g. Health: mental health, self-reported health, healthy days, disability; and Good Governance: government performance, fundamental rights, services, political participation. The first World Happiness Report was launched in 2012. ${ }^{[1]}$ There was another GNH report in 2013, ${ }^{[3]}$ which covered both the 2010 - 2012 rankings and also the changes from 2005 - 2007 to 2010 2012. The 2015 report $^{[4]}$ is just to hand. South Africa (SA) has been slipping steadily in the ranks with the publication of each report: in 2011 $1^{[1]}$ Bangladesh was 14 rungs above SA and Zimbabwe 52 rungs below us; in $2014^{[4]}$ we were ranked at $113 / 158$, in the company of Tunisia, Palestinian Territories, Bangladesh, Iran, Ukraine and Iraq, slightly above us (107 - 112), and Ghana and Zimbabwe just below us (114 - 115). It probably is no accident that 'Gross national happiness in Bhutan: The big idea from a tiny state that could change the world ${ }^{\text {[5] }}$ attracted interest in 2012 (at the Doha United Nations climate change conference), 'in a world beset by collapsing financial systems, gross inequity and widescale environmental destruction.'

Which brings one to the World Misery Index, devised by Steve Hanke, professor of Applied Economics at Johns Hopkins University, who factors together a nation's inflation, lending rates, unemployment figures and year-on-year per capita GDP growth to determine 'misery. ${ }^{[6]}$ In 2015, SA is among 'Les Miserables', with a ranking of $10 / 108$ (Bhutan ranks 44/108). ${ }^{[7]}$ The chief reason, according to Hanke, is our unemployment, which currently stands at $26 \%$ ( $40 \%$, if people who have given up are counted): 'when people are unemployed, their wellbeing is low and can be likened to the effect of bereavement or separation. Studies show that it is better to get people into bad jobs rather than no jobs at all.'[1] To add insult to injury, SA occupies second-to-last place $75 / 76$ - in an analysis ${ }^{[8]}$ based on the Organisation for Economic Cooperation and Development (OECD)'s Pisa ${ }^{[9]}$ test scores in maths and science, according to a report titled 'Universal Basic Skills: What Countries Stand to Gain', and subtitled 'Update of Employment and Educational Attainment Indicators', which has just been released by the OECD and produced by economists Eric Hanushek and Ludger Woessmann. ${ }^{[10]}$ Science, according to Carl Sagan ${ }^{[11]}$ is a way of thinking; a way of sceptically interrogating those in authority: 'if we are not able to ask sceptical questions ... then we're up for grabs for the next charlatan, political or religious, who comes ambling along. Once you give a charlatan power over you, you almost never get it back.'
Chapter 4 of the Universal Basic Skills report, in offering a comprehensive analysis of the current state of 'knowledge capital' in each country and distance from the goal of basic skills for all, reveals that some $80 \%$ of SA's students are at a disadvantage. There is some 'balm' in that even the richest countries in the world also have significant populations without basic skills, e.g. Luxembourg (25\%), Norway (22\%), the USA (24\%) and Switzerland (14\%), and one in five British students leave school without acquiring these same basic skills. $^{[8]}$

The report shows that poor quality of schooling in a country is a powerful predictor of the wealth that countries will produce in the long run. For countries, such as our own, that are rich in natural resources: 'the wealth that lies hidden in the undeveloped skills of their populations is far greater than what they now reap by extracting wealth from national resources ... the post- 2015 agenda is no longer just about providing more people with more years of schooling, but about making sure that individuals acquire a solid foundation of knowledge in key disciplines, that they develop creative, critical thinking and collaborative skills, and that they build character attributes, such as mindfulness, curiosity, courage and resilience ... knowledge and skills have become the global currency, the key to better jobs and better lives. And there is no central bank that prints this currency. We cannot inherit this currency, and we cannot produce it through speculation; we can only develop it through sustained effort and investment in people. ${ }^{[10]}$

Why raise these constructs in the journal? Because, as several papers in this edition show, the country's poor health has everything to do with the issues that determine happiness: social support, incomes, healthy life expectancy, ${ }^{[1]}$ and misery, principally unemployment. ${ }^{[6]}$ The SA quadruple burden of disease is underpinned by poverty. In this context, readers will resonate with the Prime Minister of Bhutan's recent warning of the threat to his country's happiness of 'ballooning debt that if we're not careful will not be sustainable; the big rupee shortage; unemployment, in particular youth unemployment; and a perception of growing corruption.'[12]

In 'Multimorbidity, control and treatment of non-communicable diseases among primary healthcare attenders in the Western Cape, South Africa, Folb et al. ${ }^{[13]}$ observe that of the 4500 patients they studied, $75 \%$ were unemployed and $58 \%$ were recipients of a social welfare grant. Their median income in the month prior to the study date was ZAR1 140, including personal non-grant income plus any household grant that benefited the participant, such as a disability or child grant. The results found poor disease control, high levels of multimorbidity and unmet treatment needs in primary care clinics in the public sector (in two districts in SA).

Poverty is understood to be a driving force behind the HIV/AIDS epidemic in sub-Saharan Africa as both a cause and effect of the disease, and empirical research has pointed to an association between HIV prevalence and lower socioeconomic status.

In "The case for expanding the definition of "key populations" to include high-risk groups in the general population to improve targeted HIV prevention efforts', Shisana et al. ${ }^{[14]}$ confirm that income and social inequality, as also the case in the USA among black Americans, are important, if not the chief social determinants of HIV prevalence and incidence among black South Africans.

Studying 'The mental health experiences and needs of methamphetamine users in Cape Town', Watt et al. ${ }^{[15]}$ found high rates of psychological distress, with close to half of participants scoring above the cut-off for depression and more than half 
meeting screening criteria for post-traumatic stress disorder. Many reported using methamphetamine to numb feelings, forget disturbing memories and cope with their daily lives. Yet, very few participants had ever accessed the mental health services that might provide coping and problem-solving interventions to help abusers deal with life stressors.

\section{Janet Seggie}

Editor

janet.seggie@hmpg.co.za

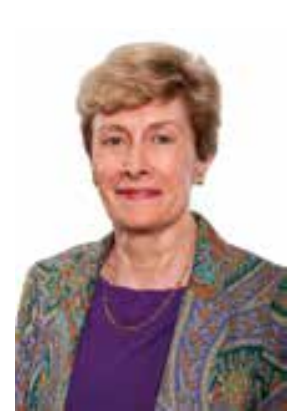

1. Helliwell J, Layard R, Sachs J, eds. World Happiness Report 2012. http://worldhappiness.report/wpcontent/uploads/sites/2/2012/04/World_Happiness_Report_2012.pdf (accessed 17 May 2015).

2. Bhutan. http://en.wikipedia.org/wiki/Bhutan (accessed 16 May 2015)

3. Helliwell JF, Layard R, Sachs J, eds. World Happiness Report 2013. New York: Sustainable Development Solutions Network, 2013. http://unsdsn.org/wp-content/uploads/2014/02/WorldHappinessReport2013 online.pdf (accessed 17 May 2015).

4. Helliwell JF, Layard R, Sachs J, eds. World Happiness Report 2015. New York: Sustainable Developmen Solutions Network, 2015. http://worldhappiness.report/wp-content/uploads/sites/2/2015/04/WHR15Apr29-update.pdf (accessed 17 May 2015).
5. Kelly A. Gross national happiness in Bhutan: The big idea from a tiny state that could change the world. http://www.theguardian.com/world/2012/dec/01/bhutan-wealth-happiness-counts (accessed 16 May 2015)

6. Hanke S. The World Misery Index: 108 countries. http://www.businessinsider.com/the-29-mostmiserable-countries-in-the-world-2015-1\#ixzz3aIHhoJTO (accessed 16 May 2015).

7. Jamrisko M, Saraiva AC, Tartar A. The 15 Most Miserable Economies in the World. http://www. bloomberg.com/news/articles/2015-03-02/the-15-most-miserable-economies-in-the-world (accessed 16 May 2015).

8. Chang N. Global school rankings: Interactive map shows standards of education across the world. http://www.independent.co.uk/news/education/education-news/global-school-rankings-interactivemap-shows-standards-of-education-across-the-world-10247405.html (accessed 17 May 2015)

9. The Programme for International Student Assessment (PISA). http://www.oecd.org/pisa/aboutpisa/ (accessed 17 May 2015).

10. Hanushek E, Woessmann L. Universal Basic Skills: What Countries Stand to Gain. http://hanushek stanford.edu/sites/default/files/publications/Universal_Basic_Skills_WEF.pdf (accessed 17 May 2015).

11. Carl Sagan. http://en.wikiquote.org/wiki/Carl_Sagan (accessed 16 June 2015).

12. BBC News. Bhutan PM casts doubts over Gross National Happiness. http://www.bbc.com/news/worldasia-23545641 (accessed 16 May 2015).

13. Folb N, Timmerman V, Levitt NS, et al. Multimorbidity, control and treatment of non-communicable diseases among primary care attenders in the Western Cape, South Africa. S Afr Med J 2015;105(8):642647. [http://dx.doi.org/10.7196/SAMInew.7882]

14. Shisana $\mathrm{O}$, Zungu $\mathrm{N}$, Evans $\mathrm{M}$, et al. The case for expanding the definition of 'key populations' to include high-risk groups in the general population to improve targeted HIV prevention efforts. S Afr Med J 2015;105(8):664-669. [http://dx.doi.org/10.7196/SAMJnew.7918]

15. Watt MH,Myers B, Towe SL, Meade CS. The mental health experiences and needs of methamphetamine users in Cape Town. S Afr Med J 2015;105(8):685-688. [http://dx.doi.org/10.7196/SAMJnew.7910]

S Afr Med J 2015;105(8):615-616. DOI:10.7196/SAMJnew.8217

NOTICE

A publication fee of ZAR5 000 will be levied for all research papers submitted to $S A M J$ after 1 September 2015, provided they are accepted for publication following peer review. 